\title{
Determinants of Export Performance of SMEs: An Empirical Analysis of Literature Pertained to India
}

\author{
Shahnawaz Khokhar \\ International Islamic University Islamabad \\ Pakistan
}

\begin{abstract}
Present study synthesized to theorize the literature pertaining to determinants of export performance of Small and medium Enterprises (SMEs) of India. This study elaborates informed insight about determinants of export performance of SMEs reported in the literature on SMEs involved in manufacturing, service and trading sector. Different tools and methods were used to find out literature on given subject. Miles and Huberman Framework (1994) is used to review the literature while Meta Analysis is done to synthesize literature in which factors having significant positive, negative and no significant impact on export performance are measured. This study contributes in theory development, policy making and in actions of SMEs. Results indicated that there are many different significant determinants of export performance of SMEs in India and states emerged differently in this regard. Firm characteristics, export marketing strategy, product quality, $R \& D$, state infrastructure and access to finance etc are found very critical positive while barriers (internal \& external) are found significant negative and firm age, external technology purchase, Indian rupee, standard domestic product and business group affiliation are found no significant determinants of export performance of SMEs based in India.
\end{abstract}

Keywords: SMEs, Export Determinants, Export Performance

\section{Introduction}

In India SMEs are defined differently on the basis of their capital/ employees etc. Such as firms that do not exceed Rs. 2.5 million are small, and firms with more than Rs. 50 million but less than Rs. 100 million are medium firms (ADBI working paper, 2016). Firms with less than 100 employees are small, and firms with 100-499 employees are medium firms (Indian National Survey, 2016). Firms which have total expenditure up to 100 million are known as SMEs and firms with more than this figure are larger firms (Jaya Prakash Pradhan and Keshab Das, 2010).

In India SMEs are critical units in manufacturing and export and contributed $42.4 \%$ in Indian economy (Asian Development Bank Institute-ADBI working paper, 2016). SMEs count about $40 \%$ of gross value addition and $50 \%$ of total manufacturing export in India (Manish Sood, 2015). SMEs contribution in Indian export is 40\% (International Monitory Fund-IMF, 2015); SMEs acquired priority place in industrial policies in India (Moktan, 2007; Agarwal, 2006; Bala Subramanya, 2005; Mintoo, 2004).

It is important to understand and keep on enhancing the understanding about what determines SMEs export performance in India. This understanding is important because of significant role that SMEs are playing in export performance of Indian SMEs. Many researchers have made efforts to explore the determinants of export performance in India such as Amit Bikram Chowdhury and Debasis Neogi (2014); Jaya Prakash Pradhan and Keshab Das (2013); Ravindra H. Dholakia and Deepak Kumar (2008); and T.N. Srinivasan and Vani Archana (2011) but country is deficient in studies that have synthesized literature in a larger extent hence the present study is meant to.

Indian economy had started its journey towards industrialization through SMEs hence it will help to draw important lessons for SMEs based in India. Therefore, main theme of research at hand is that the study is literature based, literature related to determinants of export performance of SMEs in context of India. It includes studies that have been published in the selected reputable journals (list is given in Methodology section) and the study at hand synthesizes to theorize the literature pertained to India on export performance determinants of SMEs. The study focused SMEs involved in different businesses. This includes: 
$>$ Manufacturing SMEs

$>$ Service SMEs

$>$ Trading SMEs

It is needed to check that the firms are mostly unaware of having sufficient knowledge and information about critical decisive determinants of export performance. Reference to the study of Doaee and Hosseini, 2008; business success depends upon right understanding of external market coordination and acquiring strategies to control and manage it. In this regard, main question is that, which factors influence the firms' export performance? (Sahar Rahimnezhad and Hamidreza Alipur, 2015). Therefore; we can say normally firms fall into two main traps in this regard.

1. Misunderstanding of what determines export behavior

2. Wrong selection of what determine export behavior.

So, why firms (SMEs) fail to export? There must be some hidden determinants/ factors or forces due to which firms (SMEs) fail or succeed to export. Therefore; this study intends to find/examine the determinants of export performance of SMEs on the basis of literature pertained to India.

\subsection{Research Objective:}

- To develop an informed insight about determinants determining export performance of SMEs based in India

1.2 Research Question

- What are the determinants that determine export performance of SMEs based in India?

\subsection{Significance of the Study}

\subsubsection{Contribution to Theory Development:}

This study will see the possibilities to contribute to the theory development into two ways:

I. In development of clear approach in understanding and measuring determinants that impact significantly export performance.

II. In focusing regional SMEs (Indian). Current study is to theorize the studies for advancing the knowledge of export marketing theory.

\subsubsection{Contribution To Policy Maker:}

I. The study aims to give clear guidelines to manufacturers and policy makers of SMEs industry to develop export policies and strategies that are fully accompanied with complete insight about factors/determinants that determine export performance.

II. This study will also contribute to friendly macroeconomic policies, including friendly trade policies (which provide more opportunities to export and easier access to imported raw materials and other necessary inputs)

\subsubsection{Contribution To Smes' Owners/ Actions:}

I. It will help to reduce the risk of failure and will increase the chances of success.

\section{Literature Review}

In India SMEs are critical units in manufacturing/export and contributed 42.4\% in economy (Asian Development Bank Institute-ADBI working paper, 2016). SMEs in India are actively reported as useful in about 8000 products (Jaya Prakash Pradhan and Keshab Das). SMEs count about 40\% of gross value addition and 50\% of total manufacturing export in India (Manish Sood, 2015). 7.5 Million SMEs were engaged in manufacturing in 20062007 (Development Commissioner Ministry of Micro Small \& Medium Enterprises; DCMSME, 2009). In India SMEs contribute 30\% in GDP (Economic Survey of Pakistan 2008-2009). While SMEs created 30.4 million manufacturing job (DCMSME, 2009). In India manufacturing SMEs contribute 16\% in GDP which will rise up to $26 \%$ in 2022 (Sanjeeb Kumar Dey, 2014). Such like these there are other many findings which represent value of SMEs in Indian context.

Although a literature is deficient pertaining to India that has elaborated determinants of export performance. A study of Sharma (2001), investigated the exports determinants in India using annual data for 1970-98. Ravindra H. Dholakia and Deepak Kapur's studies reported determinants under two categories e.g. internal determinants and external determinants. SMEs share of export is different in different states of India. South India is on top in 2000-2008 which contains almost half of the exports of India whereas Delhi got priority in SMEs export in contrast with other states/areas of India (Jaya Prakash Pradhan and Keshab Das). 
Indian export share with small developing countries is gradually increasing e.g. Bangladesh, Bhutan, Nepal, Sri Lanka and Thailand whereas export share has been declined as compared with China (Amit Bikram Chaowdhury and Debasis Neogi, 2014). India had started economic policy reforms in 1991 that had encouraged export performance in the country very rapidly (Ravindra H. Dholakia and Deepak Kapur). Still Indian legislative bodies have to give intensive considerations in this regard.

\section{Methodology}

Present research is literature based so Miles and Huberman framework (1994) is used to review and Meta Analysis is done to synthesize literature pertained to India. Other salient features of this research are:

- Empirical studies are included that have direct observation and experience in the field.

- Case studies are not included as of having more influence on hypothetical data.

- Different Search tools are used to find literature as follows: Bibliographical databases, Internet Search Engines, Open Access Databases and Web sites

\subsection{RESEARCH DESIGN}

\section{Research Design/ Content Analysis}

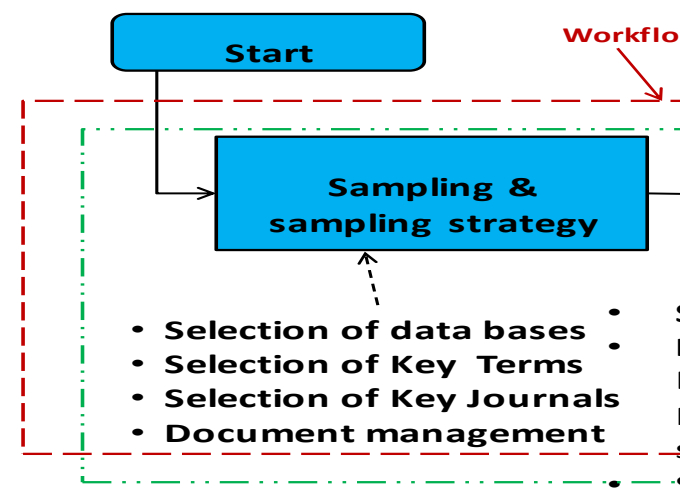

Miles and Huberman Framework (1994)

- Appraising the data/ literature

- Synthesis of data/ literature

(Reading, summarizing and synchronizing)

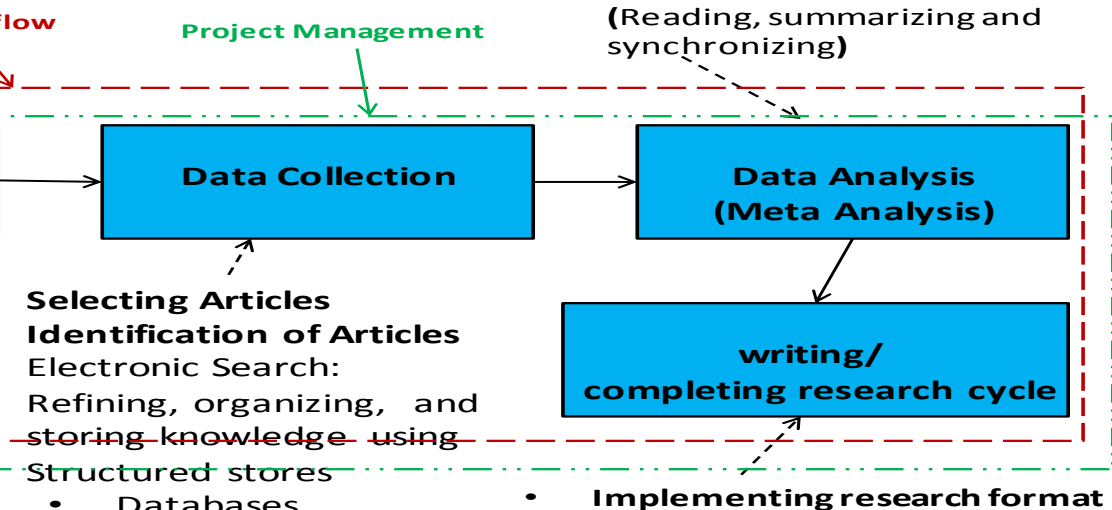

- Databases

- Data warehouses

- Report writing process

Manual Search

Figure 1: $\quad$ List of Journals

\begin{tabular}{|l|l|}
\hline INITIALL LIST OF JOURNALS & EXPANDED LIST OF JOURNALS: \\
\hline The Journal of Small Business, & \\
Journal of Management, & Journal of Business Management \& Social \\
Journal of Marketing, & Sciences Research (JBM\&SSR) \\
Journal of Management Review, & Springer \\
International Journal for Small and Medium Enterprises, & Management Research News \\
Journal of Small Business and Enterprise Development, & Management Research Review \\
Small and Medium Sized Enterprise and Entrepreneur & International Journal of Emerging Markets \\
Review, & Journal of Quantitative Economics \\
International Small Business Journal, & MPRA \\
Journal of Small Business Economics, & Universal Journal of Industrial and Business \\
International Journal of Entrepreneurial Behavior \& & Management \\
Research. & \\
\hline
\end{tabular}




\subsection{Data Analysis/ Analytical Approach}

In Data Analysis two phases are utilized:

1. Appraising the data/ literature.

2. Synthesis of data/ literature.

In appraising of data further two main functions are done.

I. Considering most relevant and useful information that is relevant to the current objectives.

II. Removing or ignoring irrelevant information that is not relevant to the current objectives.

Miles and Huberman Framework (1994) is the answer. Useful information is gathered from published works (articles) by using Miles and Huberman Framework (1994). They have suggested that qualitative data appraising consists of three stages: e.g.

1.Data Reduction: coding, writing summaries, discarding irrelevant data from literature.

2.Data Display: drawing of conclusion from mass of data/literature.

3.Conclusion Drawing/Verification: which means our analysis should allow us to begin to form conclusion about our study/primary objective which can be verified.

In synthesis of literature Meta Analysis is done. Meta Analysis is a precise approach to synthesize literature (Zau, Shaoming and S. Stan, 1998). It is a systematic review through which effect size of specific variables over others can be evaluated into a single conclusion. Meta analysis is a method of combining the data of qualitative and quantitative several studies in a systematic way to develop a single conclusion that has more statistical power. Therefore, in synthesis of data/ literature, Meta Analysis with its Hybrid Approach is done e.g. Vote counting technique summarizes each independent factor (determinants); the number of studies which have reported the impact of determinants on export performance e.g. significant positive, negative or no significant impact on export performance. Narrative approach is defined as, subjectively interpreting on the bases of knowledge of literature, the impact of determinants on export performance without showing any statistics, leaving the room for readers to make their own judgment. Whereas Hybrid approach is a combining of both Vote counting technique \& Narrative Approach of Meta Analysis.

3.3 WORK FLOW \& PROJECT MANAGEMENT: work flow (Stages) and management (research design) are correlated with each other, hence are done simultaneously with few exceptions (see research design for detailed view)

\section{Results of the Review/ Organizing Data for Inferences: General Assessment of the Reviewed Studies of India:}

a. COUNTRY STUDIED: "India"

b. PUBLICATION PERIOD: literature published in last 10 years (with few exceptions)

c. SAMPLE SIZES OF THE STUDIES REVIEWED: While using cross sectional review, sample sizes used in the Indian studies are ranged from a lowest of 40 to a highest of 8486 whereas many studies did not mention sample size or did not use samples in their studies.

d. INDUSTRY TYPE: Industry type includes manufacturing, service and trading firms. Mixed approach in this regard is used e.g. many studies targeted only manufacturing SMEs, many targeted manufacturing and service SMEs, many targeted manufacturing/ service/ and trading SMEs, No single study found which is based on service or trading sector only. It is verified that the importance of manufacturing sector SMEs in export behavior of India is inevitable. Almost all of the studies have reviewed manufacturing SMEs however it is suggested to work on service \& trading sectors too for better sustainable development in the country.

e.TYPE OF FIRMS TARGETED: Type of firms includes SMEs, SME \& L (small, medium and large enterprises), and SEs (small enterprises). Majority of the studies have focused on SMEs while few on SME \& L.

f. USE OF RESEARCH HYPOTHESIS: Many studies have used hypothesis in their theoretical assistance while many studies did not use research hypothesis.

g. THEORETICAL BASIS: Almost all the studies have used clear theoretical basis in developing their research objectives and hypothesis with reference to their research framework. Theoretical reasoning is very much encouraging. Studies are explicit in determining the relationship between internal-external factors and export performance. However few studies are found weak in this regard. 
h.DATA COLLECTION METHODS: studies have used mixed approaches e.g. through database, survey questionnaire.

\section{i. ANALYTICAL APPROACHS:}

Many analytical approaches are used in studies e.g. regression analysis, Pearson correlations, Censored Quintile Regression (CQR) based on Chernozhukov and Hong's (2002) three-step algorithm., linear regression, Tobit method, Hausman test, time series analysis, Synthesis of secondary data, comprehensive and systematic literature synthesis, econometric technique of fractional logit model, Censored Quantile Regression, metaanalysis technique, Principal Component Analysis (PCA), matrix of coefficients

\section{j. MEASURES OF EXPORT PERFORMANCE:}

Many analytical approaches are used in studies e.g. Export activities, Firm Export Intensity, Export, balance sheet data, Growth, composition, stability, Industrial characteristics, SME growth, export performance, Competitiveness, Export problems, sub national regional dimension of exports, decision to export and performance, Export performance

\section{Classification of Determinants of Export Performance}

It is very important to know that which of the determinants of export performance are internal/ external and are in the control of SMEs or otherwise. These classifications are done as they correspond with different theoretical bases e.g. resource based theory and industrial organization (IO) theory. Classification of factors into controllable and uncontrollable determinants is made on the assumptions given by Bilkey (1987) that managers can take or cannot take charge of firms' export performance. With reference to export marketing theory that classifies controllable and uncontrollable factors of export performance, internal factor are somehow in the managerial access on the contrary to external factors

Figure 2: Classification of Determinants

\begin{tabular}{|c|c|c|}
\hline & Internal & External \\
\hline Controllable & $\begin{array}{l}\text { Ownership pattern and } \\
\text { Employment structure of } \\
\text { firms } \\
\text { Capital intensity } \\
\text { Advertisement Expenditure } \\
\text { Transaction cost } \\
\text { Transportation } \\
\text { Export marketing strategy } \\
\text { Location of Firm } \\
\text { Quality of product } \\
\text { Product Diversification } \\
\text { Service characteristics }\end{array}$ & $\begin{array}{l}\text { Affiliation with Foreign Firms } \\
\text { Business Group Affiliation } \\
\text { Distance }\end{array}$ \\
\hline Uncontrollable & $\begin{array}{l}\text { Firm size } \\
\text { Firm age } \\
\text { Access to Finance } \\
\text { Institutional Factors; } \\
\text { Internal Barriers } \\
\text { Incentives } \\
\text { Management Characteristics } \\
\text { Globalization } \\
\text { Internationalization } \\
\text { Industry specific variables }\end{array}$ & $\begin{array}{l}\text { External Technology Purchase } \\
\text { State Infrastructure } \\
\text { State Domestic Product } \\
\text { Per Capita Standard Product } \\
\text { State Research and Development (R\&D) } \\
\text { Indian Rupee } \\
\text { Supplies from domestic sources } \\
\text { Market Characteristics } \\
\text { Power supply } \\
\text { GDP } \\
\text { Government policies and strategy development } \\
\text { Technology Knowledge Base } \\
\text { Business Environment } \\
\text { Input and regional factors }\end{array}$ \\
\hline
\end{tabular}




\section{Major Determinants of Export Performance Reported in Studies of India are Meta Analyzed as Under:}

\section{Firms Specific Factors/ Determinants}

Firm Characteristics; firm size and firm age in literature have shown tri-dimensional effect (+ve, -ve, and No impact) with SMEs export performance in Indian context. Firm size, firm age, R \& D, and ownership are positively related to export in India (T. N Srinivasan and Vani Archana, 2011). Flexibility, information exchange, exporter's capabilities, firm characteristic, foreign markets, governance structure are positively related to export performance (Tore Mysen, 2015).

Firm size: influences significant positive effect on export performance of SMEs in India. The result is in line with the findings of many researchers e.g. Goldar, Banga, Ravindra H. Dholakia, Deepak Kapur and T. N Srinivasan and Vani Archana, 2011 etc. Firm size has been proved as the most significant and is highest elasticity determinant of export behavior of Indian firms. Firm Size has positive coefficient for SMEs in India. However there is no specific level of size for suitable exporting behavior of firms.

Firms of different sizes export into foreign markets whereas it is accepted that firms of large sizes are more likely to observe export behavior. It is argued that firm size influences export efforts at SMEs level more up to medium to high technology sector in India (Jaya Prakash Pradhan and Keshab Das, 2013)

Firm Age: this is a time period in terms of years the firm has spent in operation. Firms' age in respect of experience; is significant determinant of export performance in India (T. N. Srinivasan and Vani Archana, 2011). Current finding in Indian context is that firm Age has +ve sign for SMEs in different states of India. This means as the firms get older they would have more age, experience, skills and human capital etc which make them able to export. Indian Firms/SMEs having over 5 years of age are more likely to perform export behavior and vice versa. Therefore experience is a major factor in export market intensity. However, age phenomenon appears differently with the nature of firms/ state of India especially with their management system and resources. Assets of firms and age of firms exist similarly in almost all types of export intensities. In India less aged SMEs are exporting units too.

Ownership pattern and Employment structure of firms: in Indian firms/ SMEs ownership stakes are very high whereas only $4 \%$ of exporting firms have private stakes below $70 \%$.

External Technology Purchase: is defined as import of technology (Ravindra H. Dholakia and Deepak Kapur, 2008). This determinant has strong positive relationship with SMEs' export behavior. SMEs producing technological products or services took much benefit of technologies from other markets (countries). Hiring the competitiveness of the other firms to combine with host firm's specialty for betterment of products/services; technology introduction and research and development spending got a special place in exporting of Indian SMEs. Firms acquired new technologies show more than 50 percent of export in contrast with firms having older technologies in India. In India main channels for technology up gradation are partners, friends, relatives, industry's association and communication channels. But firms with imported technology are better than firms with indigenous technology. As narrated that state technological specialization in manufacturing sector has positive sign in export share of SMEs (Jaya Prakash Pradhan and Keshab Das, 2014).

State Infrastructure: state infrastructure facilities are transport, power, water, roads quality etc prevailing in the given state (M. R. Narayana, 2004). State Higher Education Enrolment has negative coefficient for low technology SMEs, mobility of skilled workforce is high in between different states so lack of skilled labor in particular states does not effect export intensity of that state. Bad quality roads show negative but significant impact on SMEs export activities in line with Jaya Prakash pradhan and Keshab Das. Quality and network of roads impacted the export activities in India. Better the roads, better would be transportation hence export performance. States Port Infrastructure show +ve and significant impact on SMEs as narrated, Port facility, credit availability, and proximity to foreign firm have positive impact on SME export (Jaya Prakash pradhan and Keshab Das) Physical, Human, and Financial Infrastructure; these determinants include different variables i.e. roads, bridges, railway, seaports, airports, electricity supply and communication system etc. They show significant positive impact on export performance of SMEs in India. Human Infrastructure includes working hours per week/day/year, rate of skilled labor, education of managers, capacity development whereas for financial side, it includes interest rate, labor per hour etc. Technology Innovation, international competence, location, access to infrastructure and services, and firm resources/capabilities are important determinants of export performance with significant positive influence on export behavior of the firms in India. 
State Telecom Infrastructure: is a networking of telecom in given state, while telecommunication is a main determinant of export in India (Jaya Prakash Pradhan and Keshab Das). This shows positive impact on export but vice versa for large firms in different states of India. Study of Jaya Prakash pradhan and Keshab Das revealed that telecommunication sector (high-low) has positive impact on SME export performance. State technological knowledge stock, state telecom infrastructure and state finance availability has strongly positive coefficient for states' SMEs export share whereas spatial concentration of firms has significantly negative sign with states' SMEs export share (Jaya Prakash Pradhan and Keshab Das, 2014)

State Incident of Foreign Firms: known as presence of foreign firms in host state (Jaya Prakash Prsdhan and keshab Das). It has significant positive sign for SMEs export behavior. Presence of foreign firms effects the ability of host state firms to export, this is of dual nature e.g. sometimes it (presence of foreign firms in host state) shows positive and sometimes negative influence on firms' export behavior. State Finance Availability is influential for SMEs export behavior in India. Its coefficient is not significant for high-medium technology industries.

It shows positive sign for low technology SMEs. Firms having credit facility are more likely to show export intensity and propensity in India. Land Availability is considered as a major determinant in performance of firms. Location do impact on export intensity of firms in India, 2/3 firms considered it as major factor.

Capital Intensity: is defined as total assets spent to gain future profits (Ravindra H. Dolakia and Deepak Kapur, 2008). It provides competitive advantage to firms and it shows negative effect on export performance in Indian SMEs (Pant, 1993; (Kumar and Siddharthan, 1993)

Advertisement Expenditure has significant positive influence on export performance of firms in India (Kumar and Siddharthan, 1993). Unit Production Cost of firms tries to grasp cost based leadership in firms' products to capture market share in international markets. More the capital expenditure and capital revenues, more the chances to exhibit export functions.

Transaction cost: is defined as non price factors which are not directly related with production process (EECP, Engineering Export Promotion Council of India). Indian SMEs used to reduce their cost and risk associated with selling in foreign markets. Imports of technology, risk involved, past experience and expenditure on advertisement are main determinants of export behavior in the pre-reform period of India. However import intensity, capital intensity; product development expenditure and growth of firm are significant determinants in pre-reform era while they were not significant in post-liberalization period in India.

Quality of Product: In India quality of product means products that are satisfying standards of Bureau of Indian Standards (BIS) and Indian Standard Institution (ISI). Firms try for price elasticity of demand of their commodities/products. Product Diversification: product diversification includes product development and market extension in the economies (Ravindra H. Dolakia and Deepak Kapur, 2008). Product development with value addition shows +ve influence in Indian export however it also shows ineffective impact for SMEs with negative sign in high technology firms. Product innovation found to have positive relation with export (Luis Filips Lages et al, 2009). It is very difficult and complex to make uniqueness in intensive technology products and India is somehow declining in this regard with reference to high tech products.

Regional Determinants of SMEs Export: These are the descriptive analysis factors; researchers have also used Econometric Analysis to assess the single influence of a factor in a combination with other on export share. This survey in Indian industry revealed many determinants i.e. size, age, legal status, ownership pattern, export cost, internal cost, import duty, Government subsidy, infrastructure quality and material availability etc

State Domestic Product: is defined as sum total of values of all industries in the given state. This exhibits statistically positive coefficient for Small firms whereas negative for large firms therefore export behavior is more dependent on host state local market size. While growth standard domestic product (SDPG) has strong positive coefficient for SMEs, so states with high SDPG enable SMEs to exhibit export in India.

Per Capita Standard Product: an individual living standard over his income (Jaya Prakash Pradhan and Keshab Das). It shows intensive positive influence on export behavior of SMEs in Indian states. So the regions with higher per capita income, ultimately SMEs are more able to target foreign markets and show export competitiveness.

State Research and Development (R\&D): is defined as state R\&D parameters adopted in contrast with other states or developing countries (Jaya Prakash Pradhan and Keshab Das). It has significant positive effect on export 
performance of firms in India. This finding is in line with T. N Srinivasan and Vani Archana, 2011; Kumar and Siddharthan, 1993. Whereas sometimes, it also shows negative influence on export behavior of firms (Lall, 1981). Risk involved in research and development in overall business success implies positive impact on export performance. However the current finding is that R\&D imposes significant positive impact on export competitiveness of Indian firms in almost all states of India. However it has also been identified that some specific firms/ industries have no significant impact, somehow R\&D activities are not applicable to firms' export due to the nature of industry and financial position of the firms. This case is mostly appropriate with SMEs which have no such resources to cope with. SMEs export advantage is not merely taken through R\&D Intensity. Hence $R \& D$ intensive firms are export intensive.

Affiliation with Foreign Firms: networking with foreign firms is called affiliation with foreign firms. This shows positive sign for SMEs export. SMEs affiliated with foreign firms are more likely to export than domestic firms as there are different stakeholders involved in export behavior of the firms. This finding is in line with Jaya Prakash pradhan and Keshab Das research.

Business Group Affiliation: shows positive sign for large firms and negative sign for SMEs in India. This means SMEs affiliation with local domestic business groups has no much intensity of the export behavior of SMEs.

Transportation: movement of people and goods within states or across countries (Goitom Tesfem and Clemens Lutz, 2006; James Riedal et al, 1984). This is a positive and significant factor of export in India; more than $61 \%$ of SMEs took it a major export determinant. Poor quality of roads, railways in area cause major impact. It causes abnormal loss in operations of firms which put them in malfunctioning.

Cost of transporting products into ports is a matter of serious concern. Major portion of sales revenue is being spent on it. Easy access to ports, less cost of transportation influences export intensity and propensity in a positive way in the country.

Access to Finance: This determinant is somehow influential, highly influential and very highly influential. Financial accessibility has strong positive link with export performance of SMEs in India. It depends on the industry types, firms vary in demanding financial resources. So loan requirement appears differently as it is narrated "Percentage of Loan requirement influences negatively and significantly export performance (T. N Srinivasan and Vani Archana, 2011). Loan financing is a major determinant of export in India (Jaya Prakash Pradhan and Keshab Das). This is basically a major part of bringing competitive advantage over firms. Firms which can borrow handsome amount of finance can easily convert it into assets. It is argued that every component of a business can be purchased so firms having more funds accessibility are more likely to export. Competition from foreign investment; showed statistically significant with reverse sign for large firms and positive sign for SMEs (Jaya Prakash Pradhan and Keshab Das, 2012)

Indian Rupee: value of Indian rupee over US Dollar is considered very influential on export in 2005 onwards. Exchange Rate of Indian rupee has negative relationship with exchange rate of other developing countries' exchange rate (Amit Bikram Chaudhry and Debasis Neogi, 2014) Huge decline in export intensity was observed in the given time span however firms with low export intensity were more prone to negative impact of Indian rupee appreciation.

Supplies from domestic sources: a large portion of export behavior is reported as a result of domestic material supplies. Simple statement developed is, more raw materials- more production -more export performance. Over $90 \%$ of the firms' production is rely on local availability of material, very few firms with very low ratio, import raw material and then make exportable goods.

Institutional Factors: Institutions; are effecting export performance significantly in India (T. N Srinivasan and Vani Archana, 2011). Studies have also reported some institutional factors which significantly impact export performance of firms with varying values; although Indian economic reforms have eliminated many such factors which are negatively charged on export performance but still many of them exist. The variables include e.g. trade unionism, customs, labor regulations, corruption, conflict resolution, tax administration, regulatory policy and anti-competitive practices etc.

Internal cost factors related to export are reported more crucial. This includes cost of cargo clearance at ports, cost of transportation of consignments at ports, insurance costs, warehousing costs, cost of purchasing material, expense on machinery/ building/ land, etc. Negative and significant coefficient of these variables shows that these are hitting significantly the export performance of Indian SMEs. 
Internal Barriers and Incentives: export barriers effects export negatively and have significant coefficient. Precisely speaking incentives are positively charged in relation with export behavior of firms in India. The prominent incentives include Government schemes for export promotion and export subsidy while in Indian Industry it is reported through tobit regression that these factors show adverse impact on export intensity. We can say through this the presently available Government schemes and subsidies are not enough or significant in enhancing SMEs export behavior in India. Or SMEs are not able to get benefited through these incentives. Government and any other private or local body providing subsidies to SMEs, the SMEs perform better in export bahavior especially reported firms include gems \& jewellery, pharmaceuticals and leather industries. Export market barriers show negative impact on export performance while legal and political environment shows dual impact e.g. positive and negative impact on export competitiveness. (Pawan Kumar Chugan and Shivangi Singh, 2014)

Export Marketing Strategy (EMS): a business strategy, company uses to compete in market. The most important use of EMS is strategic decision making that has been tested with positive impact on export performance. Some strategies are product, pricing, promotion and distribution. These strategies are tested in Indian perspective and found significant and positively related with export behavior of firms. It is also observed that promotion and advertisement show negative relationship with export in smaller firms in India (those are traditional in nature). Small firms of India have shown much better movement towards international markets than domestic markets and exhibited impressive export performance in globalization era (M.H. Bala Subrahmanya, 2007)

Management Characteristics: different variables such as management export experience, level of export commitment and attitude towards export expertise etc are management characteristics. It is revealed in studies that export performance is positively related with management characteristics. Effectiveness brings efficiency. T. N Srinivasan and Vani Archana, 2011 in their study declared that managers' experience is positively related with export performance in India and skilled labor is significant in export performance.

Market Characteristics: is defined as market condition and position which strongly influences export behavior (James Riedel et al, 1984). Under this category two main sub headings are there Foreign Market Characteristics and Domestic Market Characteristic. 1st category is most important variable to cope with foreign market barriers especially for small local firms, similarly socio-cultural and political environment prevailing in foreign markets. Mostly SMEs are effected by these type of variables as compared to large firms in India. Large firms are stronger in respect of their business hence are safe to some extent. Indian SMEs are emotional upon Marketing and selling efforts; that impacts on price elasticity of demand. Market and selling effort is a brand building of the firms.

A study conducted in respect of Small-Scale Industries in India which narrated that firm's factors that contribute in firm's competitiveness in the shape of export in some state regions of Bangalore Urban Region, Northern, Coastal and Southern Regions of India. Transport Facility; that includes shipping of goods to markets, availability of containers with damage proof packaging. Market size of the state has positive relation with export behavior in high-low technology SMEs (Jaya Prakash pradhan and Keshab Das)

Market Information; small firms used to develop market strategies through getting market information about different aspect of business demand and supply of products, mechanism of export policies of the region.

Credit Facility; firms getting credit in the shape of working capital or fixed capital are more able to purchase raw material and services in the right time to achieve competitiveness so as to get product export quality. Poor credit facility however is vice versa.

Power supply: is known as availability of electricity and other resources of energy. It is the most important determinant of export behavior in developing countries. Power is a critical determinant of export in India (Jaya Prakash Pradhan and Keshab Das). Lack of power supply increases cost of goods manufactured up to unbearable level. Mostly low level income generating firms stop and firms with high reserve funds operate to meet domestic needs through their own resources e.g. installing generator systems etc. Self generating power is not feasible to SMEs. Electricity Supply and its availability position vary from firm to firm, in some cases it is a minor, major and a very serious determinant. Electricity supply and its scarcity got a serious problem in many areas of India and Pakistan too. 
GDP: Gross domestic product is a sum total of all the productions of individuals/firms within the country. India's export has positive relationship with small countries' GDP while distance has inverse and GDP has positive relationship with large countries (Amit Bikram Chaudhry and Debasis Neogi, 2014). Fiscal benefits; shows positive and statistically significant sign for large firms and SMEs (Jaya Prakash Pradhan and Keshab Das, 2012). Relative price; found to have significant positive and negative effect in some specific industries (James Riedel et al, 1984). State domestic product, growth of state domestic product, per capita state domestic product all have statistically insignificant coefficients for regional share in SMEs' total exports (Jaya Prakash Pradhan and Keshab Das, 2014)

Location of Firm: location is critically positive factor of export performance of India. Spatial concentration of firms is characterized significantly negative sign for state share of export in SMEs (Jaya Prakash Pradhan and Keshab Das, 2014). India's export is statistically insignificant to small or developing countries such as Bhutan, Sri Lanka, Nepal, Bangladesh and Thailand. On the other hand as compared to developed countries like USA, France, Germany, China and UK it is otherwise (Amit Bikram Chowdhury and Debasis Neogi, 2014)

\section{Other Decisive Determinants}

Studies pertaining to India also reflected other many decisive export determinants. Following Narrative approach they are mentioned in Table-I (See Table-I for detail)

Table-I Effects of Determinants on Export Performance

\begin{tabular}{|c|c|c|c|c|c|}
\hline $\begin{array}{l}\text { Sr. } \\
\text { No }\end{array}$ & $\begin{array}{l}\text { Country of } \\
\text { Investigation }\end{array}$ & Proposed Determinants by Literature & $\begin{array}{l}\text { Positive } \\
\text { Significant }\end{array}$ & $\begin{array}{l}\text { No } \\
\text { Significant }\end{array}$ & $\begin{array}{l}\text { Negative } \\
\text { Significant }\end{array}$ \\
\hline 1 & \multirow[t]{28}{*}{ India } & Firm size & $\sqrt{ }$ & & \\
\hline 2 & & Firm Age & & $\sqrt{ }$ & \\
\hline 3 & & $\begin{array}{l}\text { Ownership pattern and Employment structure } \\
\text { of firms }\end{array}$ & $\sqrt{ }$ & & \\
\hline 4 & & External Technology Purchase & & $\sqrt{ }$ & \\
\hline 5 & & State Infrastructure & $\sqrt{ }$ & & \\
\hline 6 & & Capital intensity & $\sqrt{ }$ & & \\
\hline 7 & & Advertisement Expenditure & $\sqrt{ }$ & & \\
\hline 8 & & Transaction cost & & & $\sqrt{ }$ \\
\hline 9 & & Standard Domestic Product & & $\sqrt{ }$ & \\
\hline 10 & & Per Capita Standard Product & $\sqrt{ }$ & & \\
\hline 11 & & State Research and Development (R\&D) & $\sqrt{ }$ & & \\
\hline 12 & & Affiliation with Foreign Firms & $\sqrt{ }$ & & \\
\hline 13 & & Business Group Affiliation & & $\sqrt{ }$ & \\
\hline 14 & & Transportation & $\sqrt{ }$ & & \\
\hline 15 & & Access to Finance & $\sqrt{ }$ & & \\
\hline 16 & & Indian Rupee & & $\sqrt{ }$ & \\
\hline 17 & & Supplies from domestic sources & $\sqrt{ }$ & & \\
\hline 18 & & Institutional Factors; & $\sqrt{ }$ & & \\
\hline 19 & & Internal Barriers & & & $\sqrt{ }$ \\
\hline 20 & & Incentives & $\sqrt{ }$ & & \\
\hline 21 & & Export marketing strategy & $\sqrt{ }$ & & \\
\hline 22 & & Management Characteristics & $\sqrt{ }$ & & \\
\hline 23 & & Market Characteristics & $\sqrt{ }$ & & \\
\hline 24 & & Power supply & $\sqrt{ }$ & & \\
\hline 25 & & GDP & $\sqrt{ }$ & & \\
\hline 26 & & Location of Firm & $\sqrt{ }$ & & \\
\hline 27 & & Quality of Product & $\sqrt{ }$ & & \\
\hline 28 & & Product Diversification & $\sqrt{ }$ & & \\
\hline
\end{tabular}




\begin{tabular}{|l|l|l|}
\hline Other Decisive & 1. Globalization, \\
Determinants: & 2. Internationalization, \\
following & 3. Service characteristics, \\
Narrative & 4. Policy variables, \\
Approach, room is & 5. Rate and distance, \\
open for readers to & 6. Government policies and strategy development, \\
decide whether & 7. Technological knowledge base, \\
they are +Ve, -Ve & 8. Business environment, \\
or No significant & 9. Input and regional factors, \\
& 10. Industry specific variables \\
\hline
\end{tabular}
Table-I

Note: following vote counting technique and Narrative Approach of Meta Analysis results are represented in

\section{Discussion and Conclusion}

In discussion section more influence is made on implications. In India, SMEs sector has taken privileged just like other many countries of the globe. All states of India intend to foster their SMEs export, however smaller states need to work more than their counterparts and state specific factors are more important in Indian context. Major landmarks for SMEs export are to achieve better quality, upgrading technology and reduced cost etc. Export in nearby countries is easy by roads provided there is better infrastructure. SMEs in India got tough time to settle technological advancements. Indian SMEs need to get rid of barriers. Barriers are the major negative determinant of export in India. Correlation between Government, SMEs, institutions, private sector and business community is required. It is suggested that demand for Indian export will increases when its export prices decreases in relation with world prices. Furthermore, the real appreciation of the rupee adversely affects Indian exports. In India, export supply is positively related with the domestic relative price of exports and higher domestic demand reduces export supply. Foreign investors appear to have statistically non significant impact on export performance, although the coefficient of Foreign Direct Investment (FDI) has a positive sign. Indian government has to boost affiliation with foreign firms in the country to settle SMEs failure in export activities. Government of India has to focus on how industrial reforms are impacting on the state export infrastructure for SMEs sector. Stable and unstable SMEs in terms of export are different to be guided in policy guidelines. Vertical integration is needed by legitimate authorities to overcome barriers especially traditional barriers in the different states of India. SMEs of India have to change their nature of remaining in the small operations; they are mostly working on their own traditional way, hence this sticky nature has to be eliminated for better sustainable development in the country.

\section{References}

Madan Annavarjula and Sam Beldona, Determinants of Managerial Risk Perceptions in Export Managers: An Empirical Examination of Indian Service Firms

Amit Bikram Chowdhury, Debasis Neogi (2014) Determinants of India's Export To Small and Large Economies:-An Analysis with Some Select Parameters, Journal of Business Management \& Social Sciences Research (JBM\&SSR), ISSN No: 2319-5614; Volume 3, No.7, July 2014

Pawan Kumar Chugan, Shivangi Singh (2014), Taxonomy for Firm-level Determinants of Export Performance, Universal Journal of Industrial and Business Management 2(1): 6-12, 2014

Ravindra H. Dholakia, Deepak Kapur (2008), Determinants of Export Performance of Indian Firms - A Strategic Perspective,

M. R. Narayana (2004), Determinants of Competitiveness of small-scale Industries in India, Small-Scale Industries in India, Volume 8 (2004)

Jaya Prakash Pradhan and Keshab Das, Exports by Indian Manufacturing SMEs Regional Patterns and Determinants, Indian Council of Social Science Research, New Delhi

Jaya Prakash Pradhan,, Keshab Das (2013) (2015),"Regional export advantage of rising power SMEs", critical perspectives on international business, Vol. 11 Iss 3/4 pp. $236-258$

Jaya Prakash Pradhan, Keshab Das (2012), Exports by Indian Manufacturing SMEs: Regional Patterns and Determinants, MPRA Paper No. 41804, posted 9. October 2012 08:36 UTC

James Riedel, Chris Hall and, Roger Grawe (1984), Determinants of Indian Export Performance in the 1970s, Weltwirtschaftliches Archiv, Bd. 120, H. 1 (1984), pp. 40-63 Springer

Rajesh K. Singh, Suresh K. Garg and S.G. Deshmukh (2009),"The competitiveness of SMEs in a globalized economy", Management Research Review, Vol. 33 Iss 1 pp. $54-65$

M.H. Bala Subrahmanya (2007); Development strategies for Indian SMEs: promoting linkages with global transnational corporations", Management Research News, Vol. 30 Iss 10 pp. $762-774$

T.N. Srinivasan, Vani Archana (2011); Determinants of Export Decision of Indian Firms: A Primary Data Analysis, Journal of Quantitative Economics, Vol. 9 No. (2), July 2011

Goitom Tesfom, Clemens Lutz (2006) A classification of export marketing problems of small and medium sized manufacturing firms in developing countries", International Journal of Emerging Markets, Vol. 1 Iss 3 pp. 262 - 281. 